\title{
Formation evaluation of an onshore appraisal well 'KG-5', “green field”, Niger Delta, Nigeria
}

\author{
O. A. Anyiam, A. W. Mode and A. C. Ekwe \\ Department of Geology, University of Nigeria, Nsukka, Enugu, Nigeria \\ okwudiri.anyiam@unn.edu.ng, wilfred.mode@unn.edu.ng and amobi.ekwe@unn.edu.ng
}

\begin{abstract}
The Well KG-5 is a vertical well drilled to evaluate an exploration prospect in the onshore "Green Field" Niger Delta. It discovered a significant oil column within the sandstone reservoir intervals. A conventional suite of wireline logs including gamma ray, calliper, sonic, density, neutron, dual laterolog and micro-SFL resistivities were acquired for formation evaluation purposes. Also two cores were cut in the reservoir interval for hydrocarbon shows analysis. The result of the formation evaluation shows that reservoir zones Q-A and Q-B contain oil while reservoirs Q-C and Q-D are water filled. The contact between the oil and water (Oil water contact-OWC/Free Water Level) is at a depth of $2464 \mathrm{~m}$. The net pay porosity values range between $0.139 \mathrm{v} / \mathrm{v}$ and $0.165 \mathrm{v} / \mathrm{v}$ with an average of about $0.158 \mathrm{v} / \mathrm{v}$. The trends of the neutron-density crossplot and the Picket plot indicate that there is a little contribution of dispersed and laminated clays in the reservoir, which would have significantly affected the poro-perm values of the reservoir intervals. Also, the net pay water saturation $(0.266 \mathrm{v} / \mathrm{v})$ is reduced as compared with the net reservoir saturation $(0.434 \mathrm{v} / \mathrm{v})$. And out of 8.080 equivalent pore column $(\mathrm{EPC}), 5.935$ are equivalent hydrocarbon column (EHC). Because the minor claystone beds within the reservoir sands are laterally continuous and may be vertical permeability barriers; the reservoir engineers should run a separate perforation for reservoirs Q-A and Q-B. This is because the two reservoirs may not be in vertical communication due to claystone baffles. And so hydrocarbon flow would be mainly horizontal.
\end{abstract}

Keywords: formation evaluation, petroleum production, petrophysical analysis, geology, hydrocarbons).

\section{INTRODUCTION:}

The Gulf of Guinea is one of the most prolific hydrocarbon provinces of the world. Intensive exploration efforts over the last 35 years in and around the Niger Delta in particular has led to a succession of significant discoveries, notably the Bonga, Agbami/Ekoli and Akpo discoveries in Nigeria. However, the full potential of the continental slope and rise seaward of the shelf break is only recently becoming apparent, with a number of exploration programs having resulted in world-class discoveries being made in recent years.

Petroleum in the Niger Delta is produced from sandstones and unconsolidated sands predominantly in the Agbada Formation. Recognized known reservoir rocks are of Eocene to Pliocene in age, and are often stacked, ranging in thickness from less than 15 meters to $10 \%$ having greater than 45 meters thickness. (Evamy et al. 1978). Based on reservoir geometry and quality, the lateral variation in reservoirs thickness is strongly controlled by growth faults; with the reservoirs thickening towards the fault within the down-thrown block (Weber and Daukoru, 1975).

Exploration and production of hydrocarbon in the Niger Delta cannot be effective without a proper evaluation of the formation with special interest on the reservoir intervals. It involves the identification and quantification of hydrocarbon resources in the subsurface and evaluation of the nature of the formation fluids. It is essential to build a realistic and dynamic reservoir and fluid distribution at and away from the wellbore to maximize the returns from the reservoir. This analysis is an evaluation of the reservoirs in the Well-KG-5; an onshore well in the Niger Delta. It is a vertical well drilled to evaluate an exploration prospect (Wildcat Well), and an appreciable oil column was discovered within the sand interval.

The objectives of this evaluation are to review available data, identify the different lithological units, complete a quantitative evaluation of clay volume, 
porosity and saturation, determine the hydrocarbon types (gas, oil and their densities) and identify hydrocarbon bearing zones and hydrocarbon-water contact; Provide average reservoir properties of porosity, saturation and net thickness for all major sand bodies, and, provide a summary report on the well results, defining techniques and parameters used.

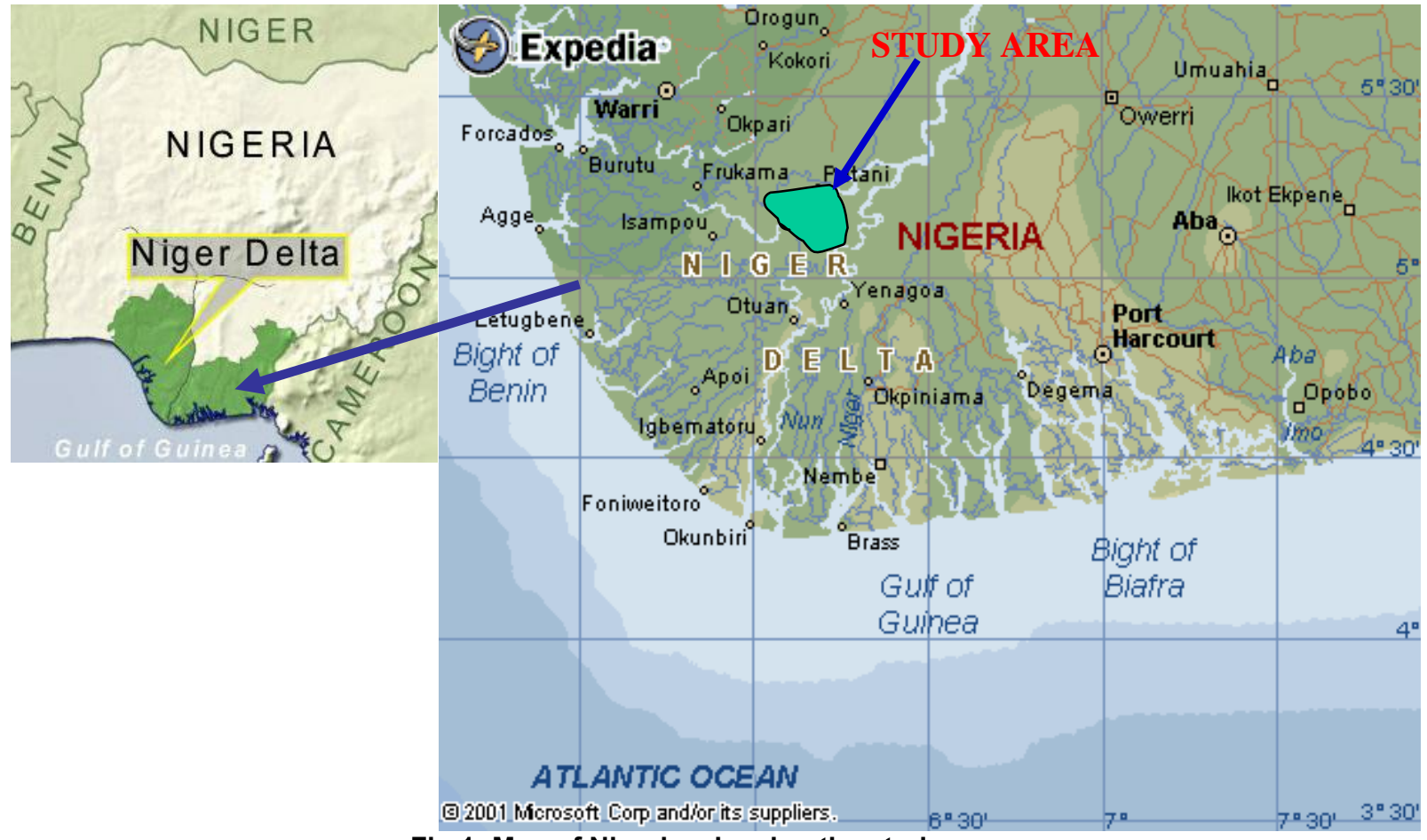

Fig.1: Map of Nigeria, showing the study area.

Stratigraphic setting: The study area (Figures 1 ) is located within the onshore western swamp, Niger Delta. The Tertiary Niger Delta covers an area of about 75,000 sqkm2 and is composed of an overall regressive clastic sequence which reaches a maximum thickness of 30,000 to $40,000 \mathrm{ft}(9,000$ to 12,000m) (Evamy et al. 1978).

Sedimentation in the basin started in the late Paleocene/Eocene, when sediments began to build out beyond the troughs between the basement horst blocks at the northern flank of the present delta area.

The structural configuration and the stratigraphy of the Niger Delta have been controlled by the interplay between rates of sediment supply and subsidence (Evamy et al. 1978; Doust and Omatsola, 1990). Eustatic sea level changes and climatic variations influence the sedimentation rates while the flexure (tectonics) of the basement and differential loading and settlement on unstable shale may have controlled the subsidence.

Hydrocarbons are concentrated along the updip or proximal edge of the successive depocenters. The Niger Delta can be subdivided lithlogically into an upper series of massive sands and gravels (Benin Formation), deposited under continental conditions (Evamy et al., 1978). This grades downward through a transitional series composed mainly of sand but with some shale, into an alternation of sandstone and shale (Agbada Formation), deposited under paralic conditions. Also, in the section below, marine shale predominates and the associated sandstone units are very likely to be turbidites (Figure 2). 
Am. J. Sci. Ind. Res., 2010, 1(2): 262-270

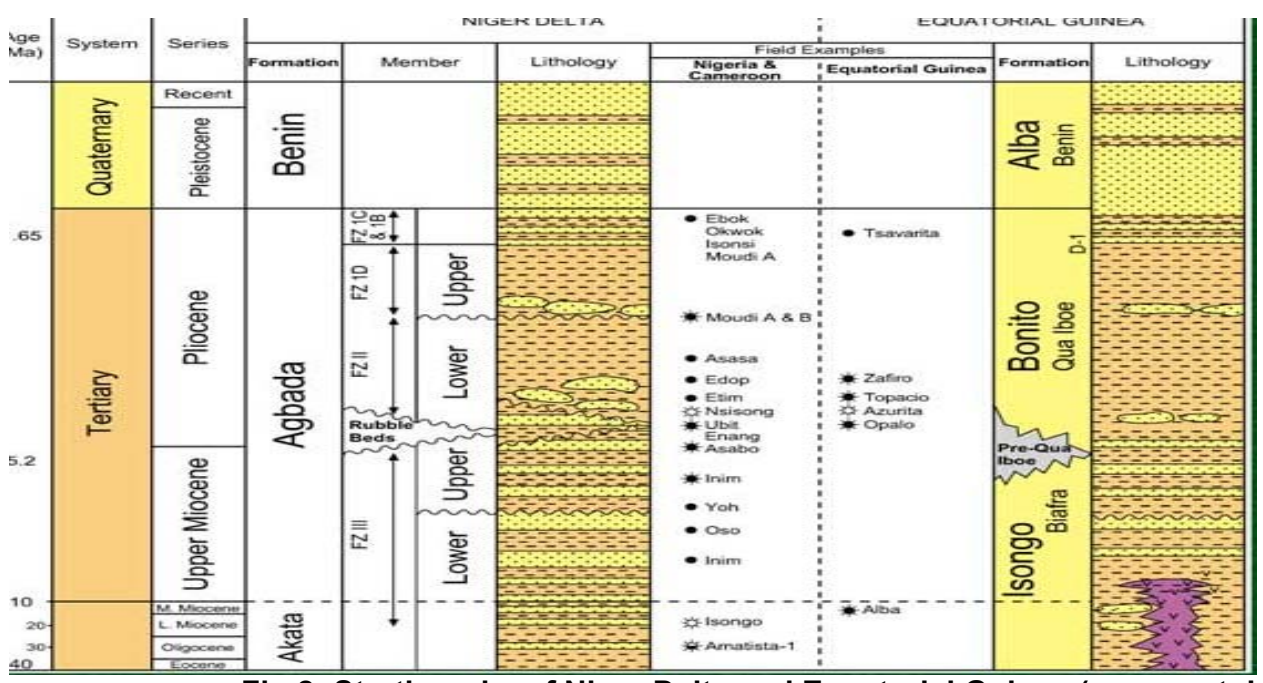

Fig 2: Stratigraphy of Niger Delta and Equatorial Guinea (www.n-stpjda.com/geo.asp)

Data review: For the evaluation of the well, a suite of wireline logs of depth intervals of $2405-2509$ meters was provided (Figure 3). These logs include Gamma ray, Caliper, Density, Neutron, Dual laterolog and micro-SFL resistivities logs.

Two core cuts were made in the reservoir intervals, namely: $2432-2436 m$ and $2438.5-2458 m$. These intervals were reported to have medium brown oil staining with yellow fluorescence and good streaming cut. Also, porosity, permeability and grain density measurements were made on the core plug samples. The lithological descriptions of the evaluation intervals were also provided. Drill stem test (DST) result was provided. This shows that oil of $45^{\circ} \mathrm{API}$ was recovered within $2424-2428 m$ on a permeability value of 52 millidarcy $(\mathrm{mD})$.

The Well elevation details above sea level were provided, and all the logs depths were measured from the drill floor elevation (DFE). All the depth evaluations were made with reference to drill floor elevation.

A formation pressure data acquired with a Repeat Formation Tester (RFT) tool between $2409 \mathrm{~m}$ and

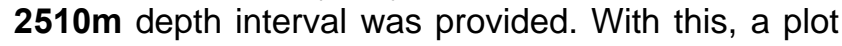
of formation pressure with depth was done to evaluate the fluid types and contacts.

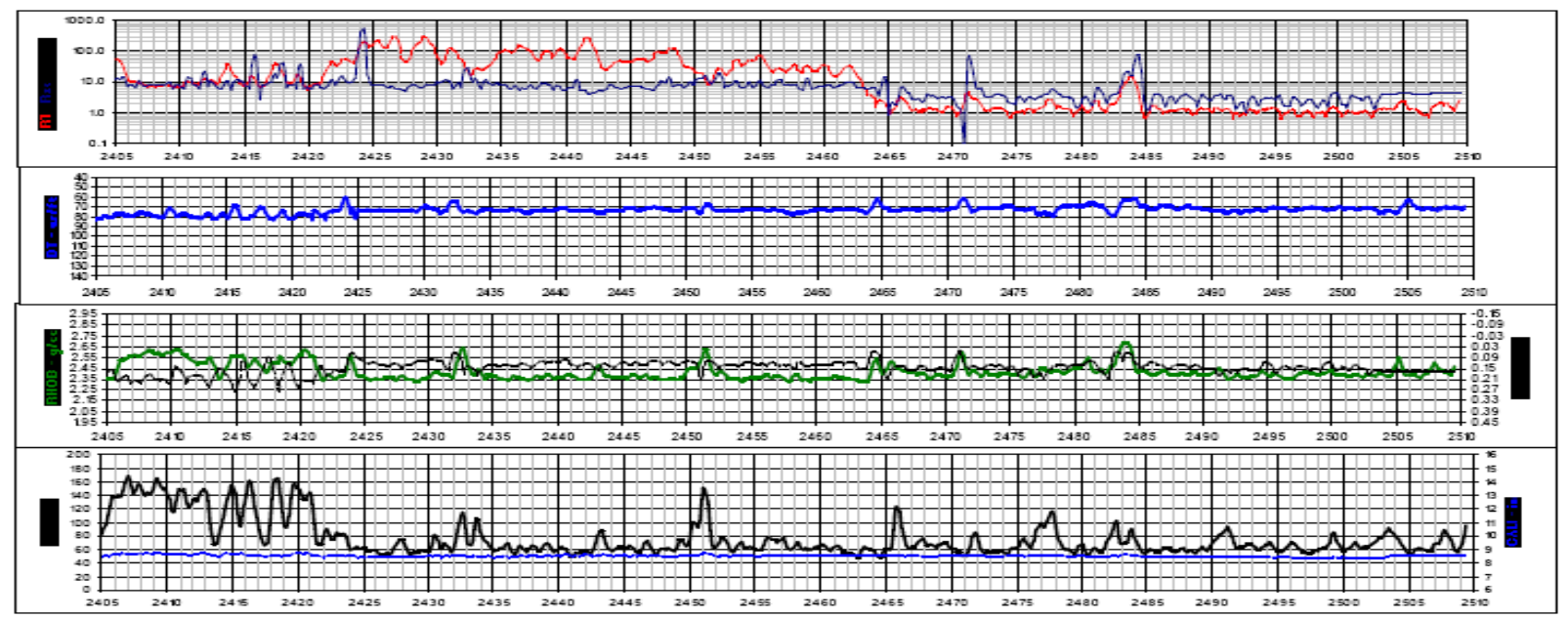

Fig 3: Suite of wireline logs for the analysis (2405-2509m)

A salinity measurement of $95,000 \mathrm{ppm} \mathrm{NaCl}$ equivalent, measured from the formation water samples from $2470 \mathrm{~m}$ and $2500 \mathrm{~m}$ by an RFT sampling tool at a bottom hole temperature (BHT) of $88^{\circ} \mathrm{C}$ was also provided. 
There were no special core analysis measurements done on the core samples for the saturation parameters. A permeability value as low as $1 \mathrm{mD}$ was expected from the sandstones for oil to flow from the pore throats into the wellbore.

\section{METHODOLOGY:}

Different petrophysical techniques were applied to get acceptable values for the different parameters. These parameters are;
1. Clay Volume: The techniques applied to estimate the clay volume are; (a) Single log technique: Gamma Ray, and (b) Crossplot techniques: Neutron-Density and Neutron-Sonic

The application of these techniques involves the estimation of the shale/wet clay properties from the logs. Two wet clay intervals with their corresponding properties were sampled as shown in the table 1 below:

Table 1: Zonation for Shale/Wet Clay Properties

\begin{tabular}{|l|l|l|l|l|l|l|l|l|l|l|}
\hline \multicolumn{4}{|c|}{ Zone Intervals } & \multicolumn{5}{c|}{ Matrix Properties } & \multicolumn{3}{c|}{ Shale/Wet Clay Properties } \\
\hline $\begin{array}{l}\text { Zone } \\
\text { Name }\end{array}$ & $\begin{array}{l}\text { Top } \\
(\mathrm{m})\end{array}$ & $\begin{array}{l}\text { Base } \\
(\mathrm{m})\end{array}$ & $\begin{array}{l}\text { GR } \\
(\mathrm{api})\end{array}$ & $\begin{array}{l}\text { Density } \\
(\mathrm{g} / \mathrm{cc})\end{array}$ & $\begin{array}{l}\text { Neutron } \\
(\mathrm{v} / \mathrm{v})\end{array}$ & $\begin{array}{l}\text { Sonic } \\
(\mu \mathrm{s} / \mathrm{ft})\end{array}$ & $\begin{array}{l}\text { GR } \\
(\mathrm{api})\end{array}$ & $\begin{array}{l}\text { Density } \\
(\mathrm{g} / \mathrm{cc})\end{array}$ & $\begin{array}{l}\text { Neutron } \\
(\mathrm{v} / \mathrm{v})\end{array}$ & $\begin{array}{l}\text { Sonic } \\
(\mu \mathrm{s} / \mathrm{ft})\end{array}$ \\
\hline $\mathbf{1}$ & 2405 & 2413 & 48 & 2.65 & -0.03 & 55.5 & 160 & 2.58 & 0.23 & 79 \\
\hline $\mathbf{2}$ & 2414 & 2421.5 & 48 & 2.65 & -0.03 & 55.5 & 160 & 2.56 & 0.28 & 82 \\
\hline
\end{tabular}

From the two sampled intervals, it was only Zone-2 $(2414-2421.5 \mathrm{~m})$ that showed a clear indication of $100 \%$ wet clay point. The parameters of the Zone-2 plotted well on the GR-crossplot and also plotted outside the dolomite line of the Neutron-Density
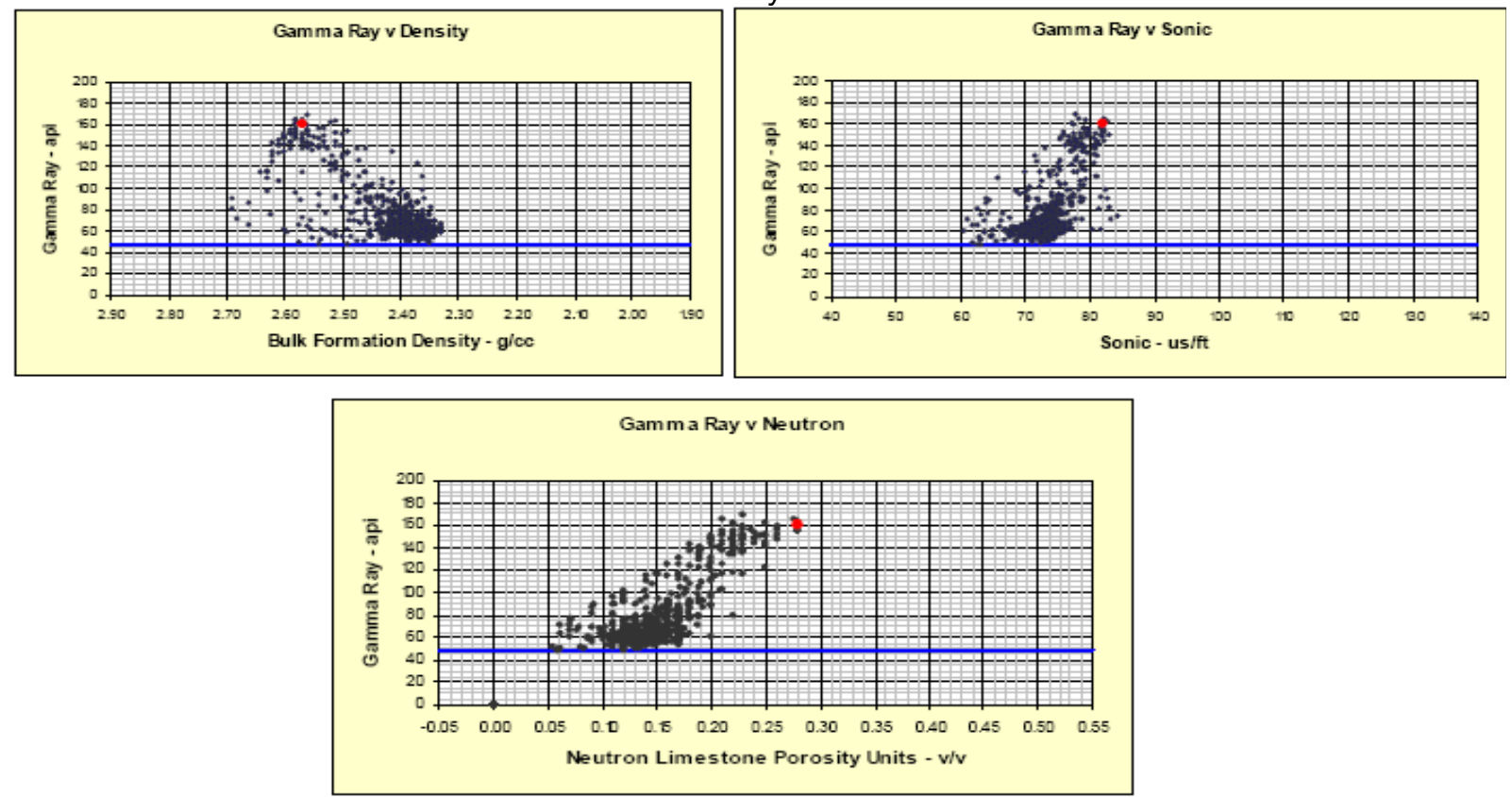

Fig 4: Gamma Ray -Crossplot (for Bulk Density, Sonic and Neutron Porosity) 
Am. J. Sci. Ind. Res., 2010, 1(2): 262-270

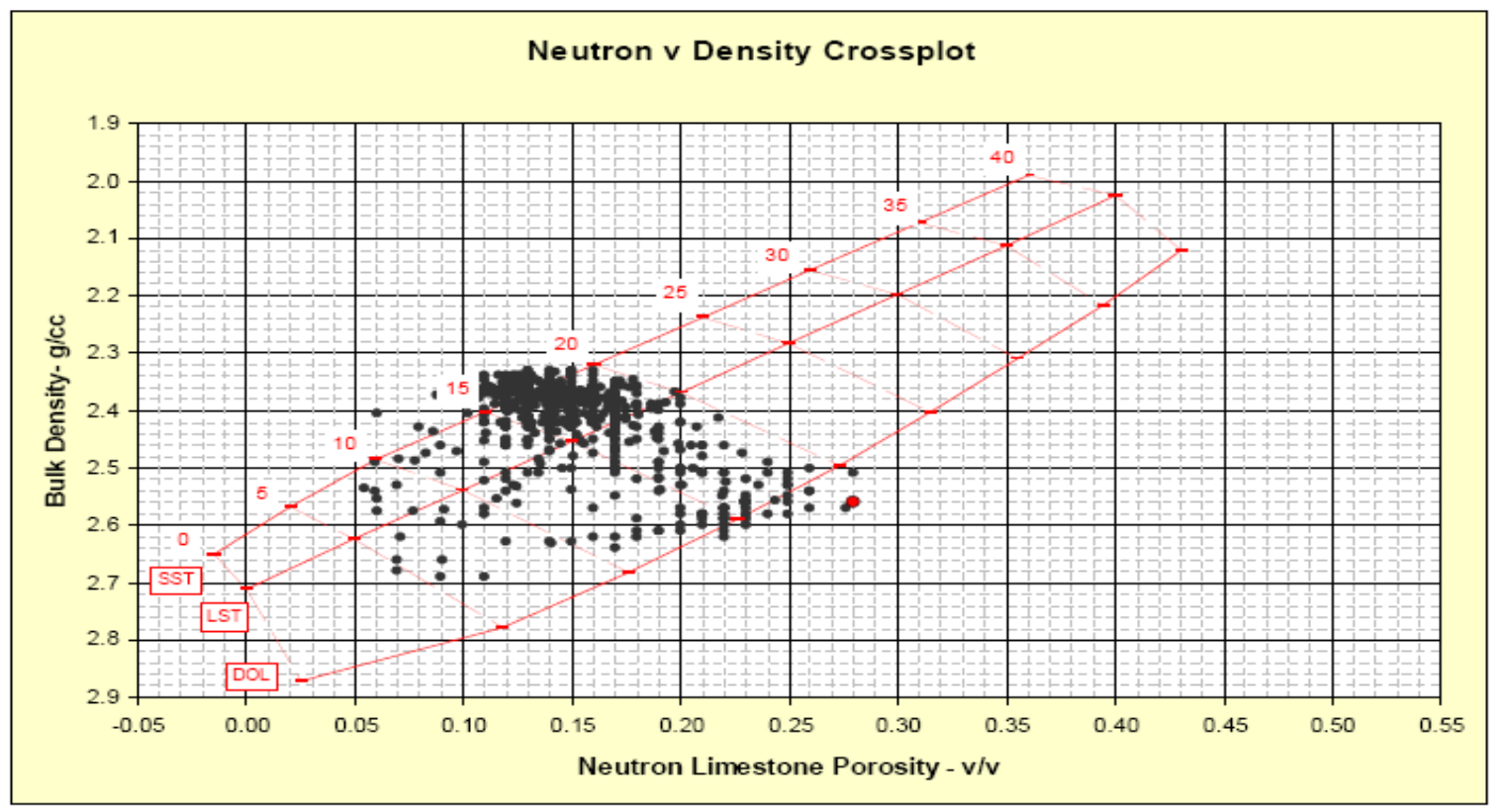

Fig 5: Neutron-Density Crossplot (Red dot = clay point) As the shale/wet clay and matrix properties of the preferred interval were put in the parameter spreadsheet, the clay volume values were estimated from gamma ray, neutron-density and neutron-sonic techniques. The gamma ray method was adopted as the final Vshale option after proper review of the results from all the techniques applied (Figure 9).

\section{Porosity:}

The estimation of porosity was done using the porosity sensitivity logs with their assumptions. These logs are: Density: It has linear response with porosity; Neutron: It has non-linear response with porosity except in limestone, i.e. the neutron log value of a formation is equal to the value of porosity; and Sonic: It has linear and non-linear response with porosity. The assumptions are that rock matrix is homogeneous, and pore fluid composition is constant.

These logs make use of the basic tool response equation for clean sands.

$\mathbf{L}=\mathbf{V}_{\mathrm{ma}} \times \mathbf{L}_{\mathrm{ma}}+\boldsymbol{\varnothing} \times \mathrm{L}_{\mathrm{fl}}$ Where $L$

$\mathrm{V}_{\mathrm{ma}}$
$\varnothing$
$\mathrm{L}_{\mathrm{ma}}$
$\mathrm{L}_{\mathrm{fl}}$

Bulk formation log response

Matrix Volume

$\varnothing \quad$ Pore Volume (porosity)

$L_{\text {ma }} \quad$ Log response in $100 \%$ matrix

$\mathrm{L}_{\mathrm{fl}} \quad$ Log response in $100 \%$ pore fluid

So, the basic porosity equation derived from the basic tool response equation for clean formations is given as: $\rightarrow \boldsymbol{\varnothing}=\left(\mathbf{L}_{\mathrm{ma}}-\mathbf{L}\right) /\left(\mathbf{L}_{\mathrm{ma}}-\mathbf{L}_{\mathrm{fl}}\right)$

As these parameters were extracted from the porosity logs as reflected in the parameter table
(Tables $3 \& 4$ ) and the raw log data, the spreadsheet calculates the total porosities from density, neutron and sonic logs. Note that the compaction factor was considered in the porosity calculation from sonic log (Tables 3 \& 4)

The estimated total porosity from logs was corrected for shale volume using standard equation for correcting total porosity for clay: $\varnothing \mathrm{E}=\varnothing \mathrm{T}-$ Vclay $x$ $\varnothing$ clay.

Where $\varnothing \mathrm{E} \quad$ Clay corrected effective reservoir porosity - v/v

ØT Total formation porosity $-\mathrm{v} / \mathrm{v}$

Vclay Clay volume - v/v

Øclay Total porosity in clay

So, correcting for clay removes that proportion of the total formation porosity that is associated with clays/clay bound porosity and gives an estimate of the effective reservoir porosity. Finally, the DensityVshale corrected was chosen as final porosity option from the spreadsheet.

\section{Water Saturation:}

This involves the identification of the cleanest sand interval with the lowest resistivity value that can be used in addition to formation water resistivity to plot the Pickett. In doing this, two sand intervals were delineated and plotted as shown in table 3 below. But the combination of the two intervals was better on the Pickett plot. So, it became the water bearing zone for the Pickett plot (Figure 6). 
Am. J. Sci. Ind. Res., 2010, 1(2): 262-270

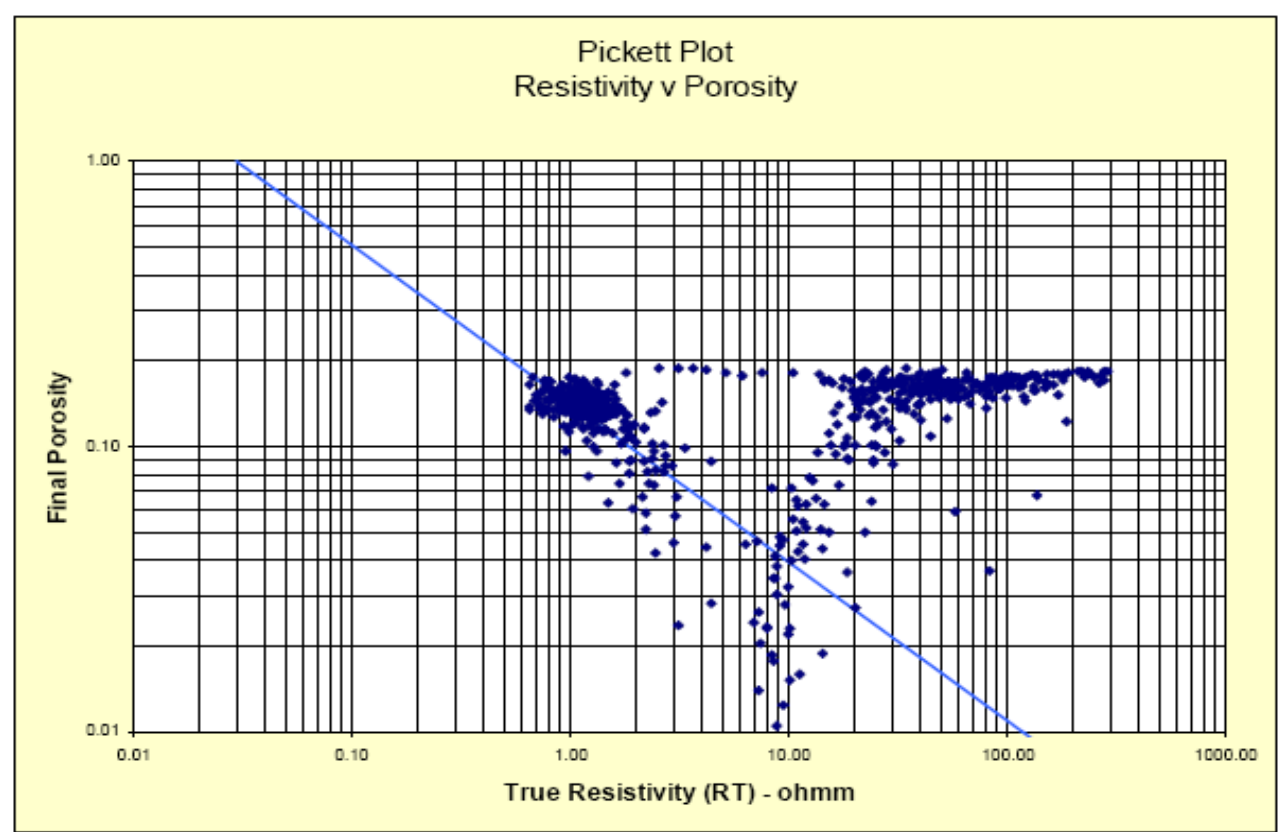

Fig 6: Picket Plot (Plot of Resistivity vs Porosity)

The 95,000ppm salinity and the bottom hole temperature $(\mathrm{BHT})$ of $88^{\circ} \mathrm{C}$ were plotted on the pore water resistivity chart to get the formation water resistivity (Rw) as 0.03 ohmm. Also, the saturation exponent " $\mathrm{n}$ " was kept at " 1 " while the cementation factor " $m$ " was varied up to 1.90 for the Pickett plot to look acceptable. Note that the Pickett plot is a graphical solution of the basic Archie saturation principles. The value of Rt at the intercept of the line with $100 \%$ porosity is the product value of "a* Rw". So as the values of the saturation parameters in table 2 above were put in the parameter sheet (Table 2), the saturation was calculated for "Archie" and "Indonesia" using the saturation equation as $S w^{n}=a^{*} R w / \varnothing^{m *} R t$,

Table 2: Zonation for $\mathbf{1 0 0 \%}$ water Bearing Sand Intervals (used in Pickett plot)

\begin{tabular}{|c|c|c|c|c|c|c|c|c|c|c|c|c|}
\hline \multicolumn{4}{|c|}{ Zone Interval } & \multicolumn{2}{|c|}{ Pore Fluid Properties } & \multicolumn{5}{c|}{ Saturation Parameters } & Remarks \\
\hline $\begin{array}{c}\text { Zone } \\
\text { Name }\end{array}$ & $\begin{array}{c}\text { Top } \\
(\mathrm{m})\end{array}$ & $\begin{array}{c}\text { Base } \\
(\mathrm{m})\end{array}$ & $\begin{array}{c}\text { Density } \\
(\mathrm{g} / \mathrm{cc})\end{array}$ & $\begin{array}{c}\text { Neutron } \\
(\mathrm{v} / \mathrm{v})\end{array}$ & $\begin{array}{c}\text { Sonic } \\
(\mu \mathrm{s} / \mathrm{ft})\end{array}$ & $\begin{array}{c}\text { Rw } \\
(\mathrm{ohm})\end{array}$ & $\begin{array}{c}\text { Rw Temp } \\
(\text { Deg C })\end{array}$ & $\mathrm{a}$ & $\mathrm{M}$ & $\mathrm{n}$ & Rclay \\
$(\mathrm{ohm})$ & \\
\hline 1 & 2485 & 2490 & 1.0 & 1.0 & 189 & 0.03 & 88 & 1.0 & 1.90 & 2.0 & 6.5 & Good \\
\hline 2 & 2492 & 2502 & 1.0 & 1.0 & 189 & 0.03 & 88 & 1.0 & 1.85 & 2.0 & 6.5 & Good \\
\hline $\mathbf{1 \& 2}$ & 2485 & 2502 & 1.0 & 1.0 & 189 & 0.03 & 88 & 1.0 & 1.90 & 2.0 & 6.5 & Better \\
\hline
\end{tabular}

Where; $\mathrm{Sw}=$ water saturation (fractional); $\mathrm{n}=$ saturation exponent; $\mathrm{a}=$ Archie exponent; $\mathrm{m}=$ cementation factor; $\varnothing=$ porosity (fractional); Rw = formation water resistivity at formation temperature; $\mathrm{Rt}=$ true resistivity of the formation.

The Indonesian saturation model with Vshale correction was chosen as the final saturation option (Figures 9).

\section{Net Reservoir and Pay Cut-offs:}

Four sand intervals (Q-A to Q-D) were delineated within the reservoir interval of 2421.5m - 2509.5m (Tables 3, 4, and Figure 9) to define the Net reservoir. 
Am. J. Sci. Ind. Res., 2010, 1(2): 262-270

Table 3: Reservoir Zone Cut-Off Selection for Well KG-5

\begin{tabular}{|c|c|c|c|c|c|}
\hline \multicolumn{2}{|c|}{ Zone Selection } & \multicolumn{3}{c|}{ Cut-off Selection } \\
\hline Zone Name & Top & Base & Vclay <= & Por => & 0.10 \\
\hline Q-A & 2421.5 & 2450.5 & 0.60 & 0.10 & 0.70 \\
\hline Q-B & 2450.5 & 2465.0 & 0.60 & 0.10 & 0.80 \\
\hline Q-C & 2465.0 & 2490.0 & 0.60 & 0.10 & 0.85 \\
\hline Q-D & 2490.0 & 2509.5 & 0.40 & 0 \\
\hline
\end{tabular}

The maximum values of Vclay and the minimum values of water saturation that define the reservoir units were chosen as shown in table 3. The cut-off for porosity was determined from the core porositypermeability plots (Figure 7). Here, it was given that oil production might be expected from sandstones with permeability as low as $1 \mathrm{mD}$. From the plot, the best porosity cut-off for the entire reservoir unit is $0.10 \mathrm{v} / \mathrm{v}$ (Figure 6). With these defined cut-offs on table 8, the Net reservoir and Net pay intervals between 2421.5m and 2509.5m depth were estimated from the spreadsheet (Figures 9).

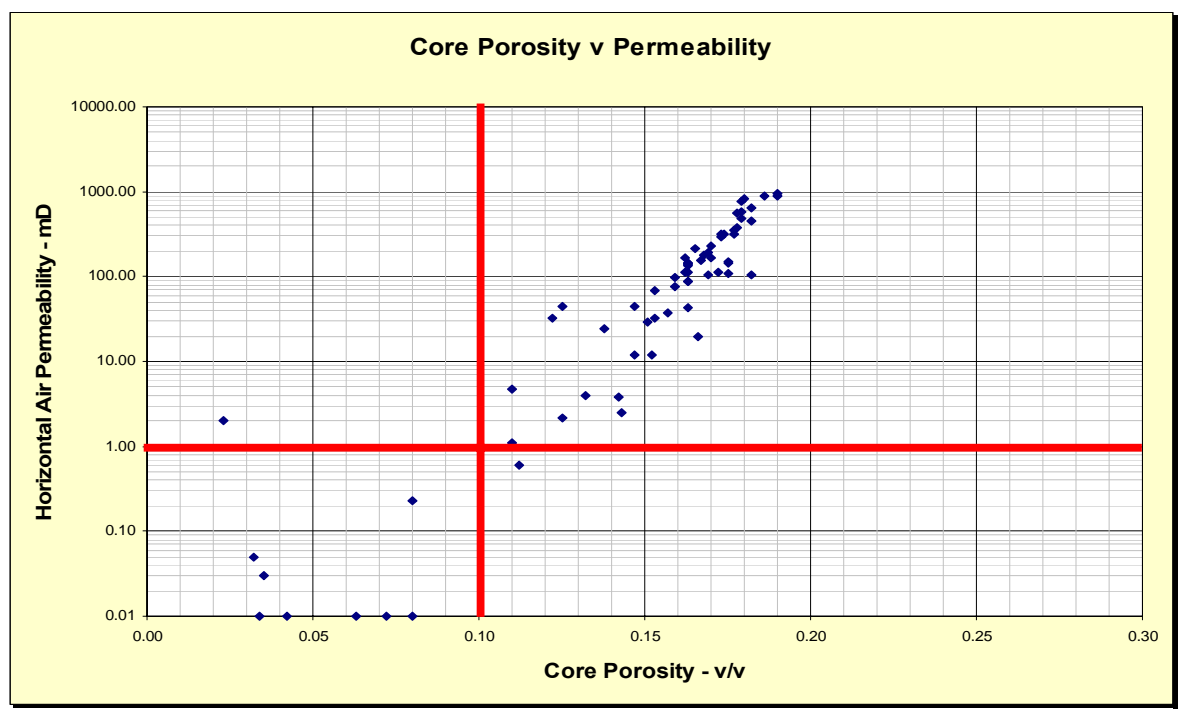

Fig 7: Core Porosity-Permeability Plot

\section{DISCUSSION ON RESULTS:}

Lithology: The evaluated log interval $(2405 \mathrm{~m}$ $2509.5 \mathrm{~m}$ ) has two major lithological units based on gamma ray log; namely: the overlying claystones with thin interbedded sandstone $(2405-\mathbf{2 4 2 1 . 5 m})$, and the underlying massive sandstone with occasional carbonate bands that show sharp gamma ray spikes within a low gamma ray value sand interval $(2421.5 \mathrm{~m}$

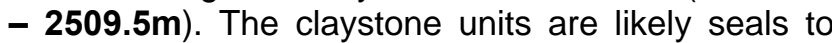

the underlying massive sandstone unit that accommodated the oil and water column in the Well.

Reservoir Properties - Zone Averages:

The reservoir properties with the corresponding cutoff are shown in table 3 above and table 4 below. Reservoirs Q-A and Q-B have high Net pay thickness, equivalent porosity column (EPC) and equivalent hydrocarbon column (EHC) than reservoirs Q-C and Q-D respectively (Table 4). The low water saturation values in Q-A and Q-B intervals 
is indicative of their high EPC and EHC values, which implies high oil accumulation and better yield.
The reservoir zones with their individual and average net reservoir and net pay properties are summarised in the table 4 below:

Table 4: Net Reservoir and Net Pay Zones with their Fluid Contents

\begin{tabular}{|c|c|c|c|c|c|c|c|c|c|c|c|c|c|}
\hline \multicolumn{3}{|c|}{ Zone Intervals } & & \multicolumn{4}{|c|}{ Net Reservoir } & \multicolumn{6}{|c|}{ Net Pay } \\
\hline $\begin{array}{l}\text { Zone } \\
\text { Name }\end{array}$ & $\begin{array}{l}\text { Top } \\
\text { (m) }\end{array}$ & $\begin{array}{c}\text { Base } \\
(\mathrm{m})\end{array}$ & $\begin{array}{c}\text { Gross } \\
\text { (m) }\end{array}$ & $\begin{array}{c}\text { Thick } \\
\text { (m) }\end{array}$ & N/G & $\begin{array}{c}\text { Porosity } \\
\text { (v/v) }\end{array}$ & $\begin{array}{l}\text { Sw } \\
(\%)\end{array}$ & $\begin{array}{l}\text { Thick } \\
(\mathrm{m})\end{array}$ & $\begin{array}{c}\text { Porosity } \\
\text { (v/v) }\end{array}$ & $\begin{array}{l}\text { Sw } \\
(\%)\end{array}$ & EPC & EHC & Remarks \\
\hline Q-A & 2421.5 & 2450.5 & 29.0 & 27.0 & 0.930 & 0.160 & 0.104 & 27.0 & 0.160 & 0.104 & 4.321 & 3.870 & Oil \\
\hline Q-B & 2450.5 & 2465 & 14.5 & 12.5 & 0.862 & 0.165 & 0.198 & 12.5 & 0.165 & 0.198 & 2.068 & 1.658 & Oil \\
\hline Q-C & 2465 & 2490 & 25.0 & 20.3 & 0.811 & 0.137 & 0.859 & 6.2 & 0.139 & 0.742 & 0.866 & 0.223 & Water \\
\hline Q-D & 2490 & 2509.5 & 19.5 & 18.0 & 0.922 & 0.146 & 0.709 & 5.5 & 0.150 & 0.778 & 0.825 & 0.183 & Water \\
\hline $\begin{array}{c}\text { All } \\
\text { Zones }\end{array}$ & 2421.5 & 2509.5 & 87.8 & 77.7 & 0.885 & 0.152 & 0.434 & 51.2 & 0.158 & 0.266 & 8.080 & 5.935 & \\
\hline
\end{tabular}

\section{Fluids and Fluid Contacts:}

The fluids identification and their contact was reliably done with the formation pressure - depth plot (Figure 8). From the plot, the fluids in the reservoirs are oil and water. The oil - water contact (OWC) occurred at a depth of $2464 \mathrm{~m}$. From the Well log, it was observed that reservoirs Q-A and Q-B are oil filled while reservoirs Q-C and Q-D are water filled (Figures 8 and $9 \mathrm{~B})$.

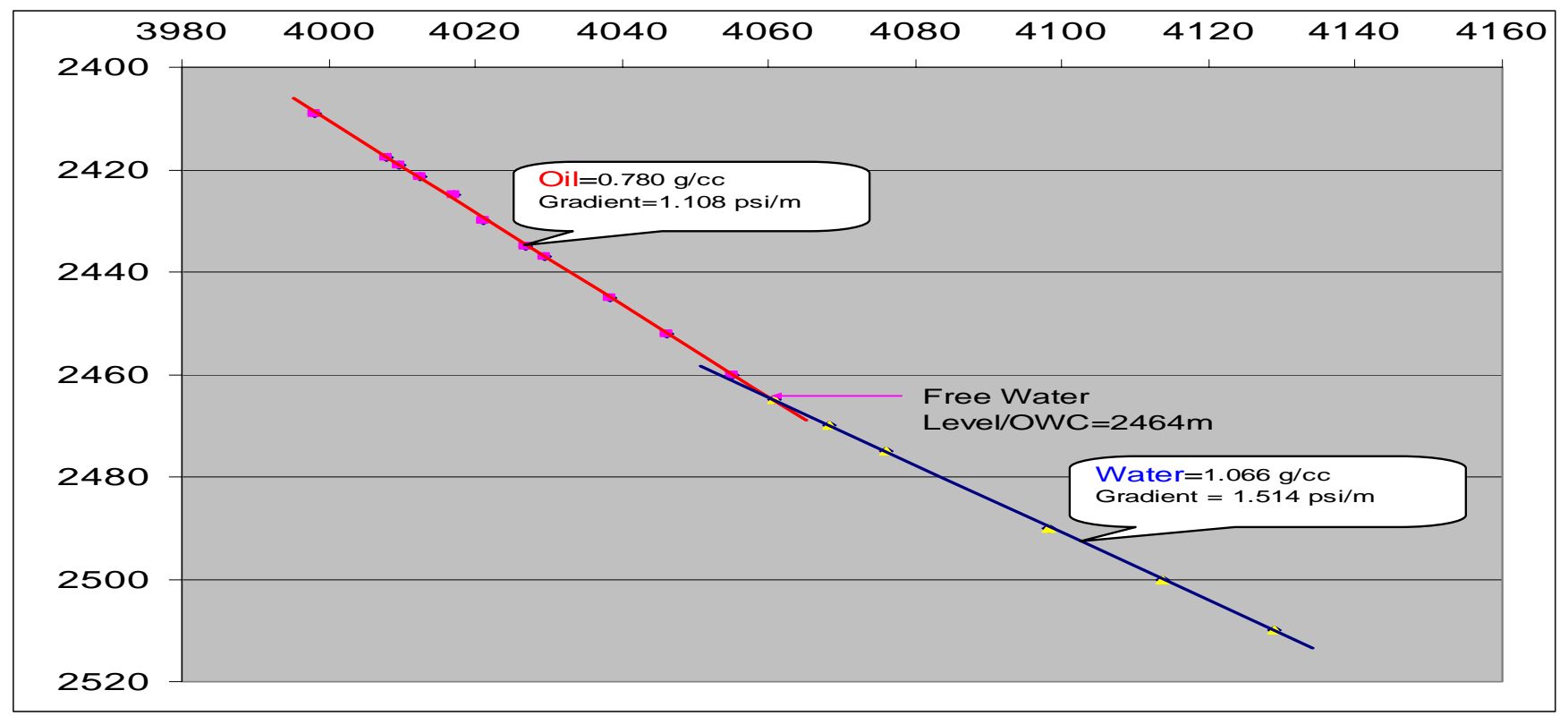

Fig 8: Plot of Pressure (psi) versus Depth (m) 
Am. J. Sci. Ind. Res., 2010, 1(2): 262-270

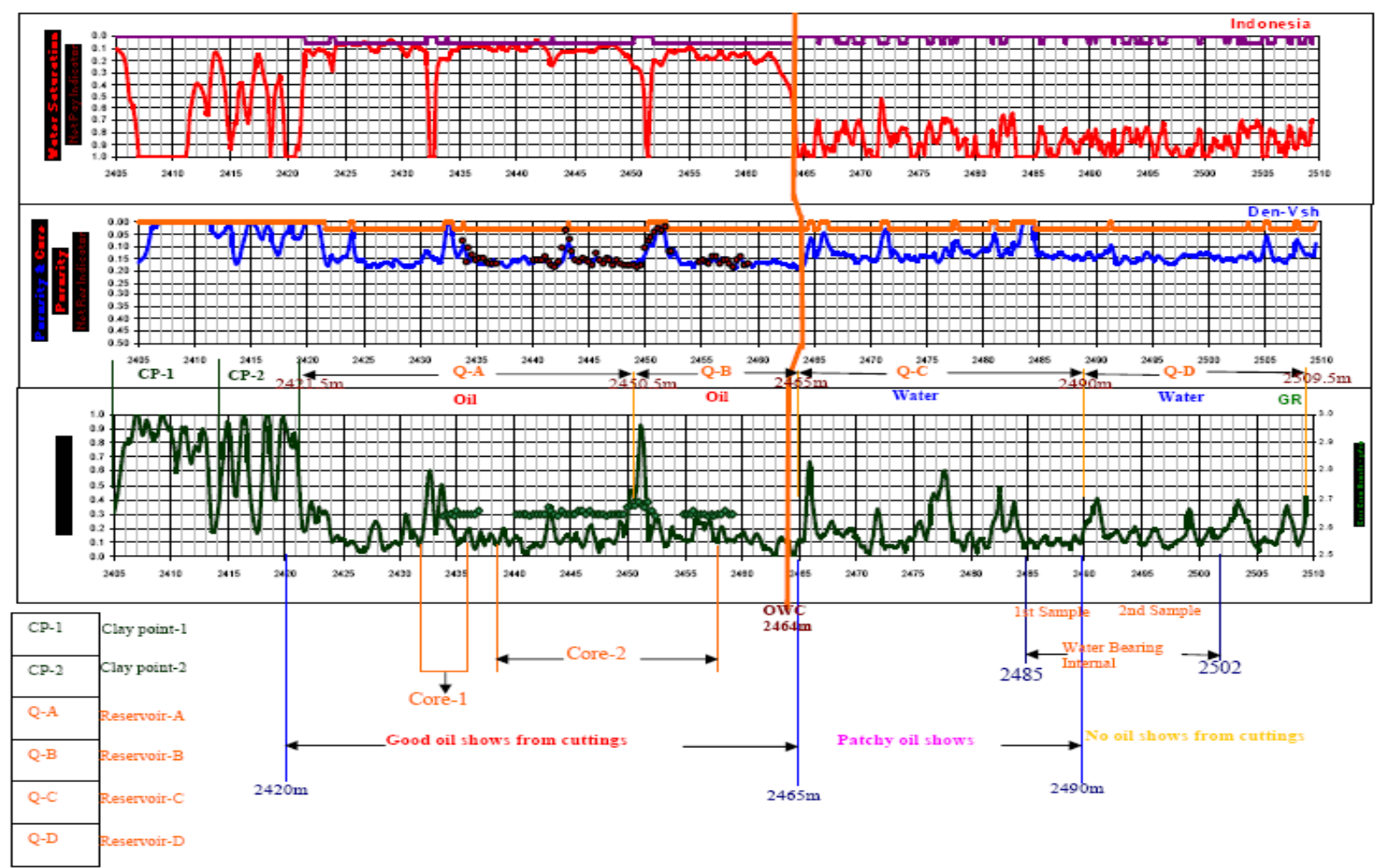

Fig 9: Result Plot Showing Zone Boundaries, Zone Names, OWC and their depths

\section{CONCLUSION:}

The result of the formation evaluation shows that reservoir zones Q-A and Q-B contain oil while reservoirs Q-C and Q-D are water filled. The contact between the oil and water (Oil water contactOWC/Free Water Level) is at a depth of $2464 \mathrm{~m}$ (Figures 8 and 9).The reservoir zones with their individual and average reservoir properties are summarised in the table 4 above. Also, the net pay water saturation $(0.266 \mathrm{v} / \mathrm{v})$ is reduced as compared with the net reservoir saturation $(0.434 \mathrm{v} / \mathrm{v})$. And out of 8.080 equivalent pore column (EPC), 5.935 are equivalent hydrocarbon column (EHC).

Because the minor claystone beds within the reservoir sands are laterally continuous and may be vertical permeability barriers; the reservoir engineers should run a separate perforation for reservoirs Q-A and Q-B. This is because the two reservoirs may not be in communication vertically due to claystone baffles. And so hydrocarbon flow would be mainly horizontal.

\section{REFERENCES:}

Archie, G.E. 1942. The electrical resistivity log as an aid in determining some reservoir characteristics. Journal of Petroleum Technology, 5, pp. 54-62.
Asquith, G. \& Krygowski, D. 2004. Basin Well Log Analysis. AAPG Methods in Exploration Series, 16.

Doust, H., \& Omatsola, E. M. 1990. Niger Delta. In Divergent/passive margin basins. AAPG Memoir, 45. (Edwards, D. \& Santagrossi, P. A., eds), Tulsa Oklahoma, P.201-238.

Evamy, D. D., Haremboure, J., Kamerling, P., Knaap,W. A., Molloy, F. A. \& Rowlands, P. H. 1978. Hydrocarbon habitat of Tertiary Niger Delta. AAPG bulletin, 62. pp.139.

Expedia maps 2001. Microsoft Corp and/or its suppliers.

Helge, L. 2005. Clay Contents from Well Data: A lecture module. Norwegian University of Science and Technology.

Helge, L. 2006. Pickett Plot: Lecture Module, V. 10. Norwegian University of Science and Technology. http://www.learningiournal.net.

Shell/Schlumberger, 1999. Petrophysics Distance Learning. Hague, Netherlands.

Stocks, A. E. 2002. Formation Evaluation. Petroleum Geosciences MSc Lecture Notes. University of Manchester, United Kingdom. 2, pp.23-59.

Weber, K. J. \& Daukoru, E. 1975. Petroleum geology of the Niger Delta. $9^{\text {th }}$ World Petroleum Congress Proceedings, 2, pp. 209-221.

www.n-stpjida.com/geo.asp 